\title{
Nursing students' experiences of change: from a traditional curriculum to a competency-based curriculum
}

Experiencias de estudiantes de enfermería frente al cambio: desde un currículo tradicional a uno por competencias

Experiências de estudantes de enfermagem frente à mudança: desde um currículo tradicional a um por competências

Margarita Poblete Troncoso*; Carmen Gloria Cofre Gonzalez**; Verónica Teresa Guerra Guerrero***;

Carmen Gloria Miño Gonzalez ${ }^{* * * *}$; Paula Anrea Ceballos Vasquez ${ }^{* * * * *}$; Ana Verónica Jara Rojas*****

\section{Abstract}

Background: In the past decade, nursing education has initiated important curricular changes based on competency training. The discipline faces the challenge of defining the most relevant competencies for students to acquire. Objective: To understand the experiences of students from the Catholic University of the Maule, Chile about competency-based education.

Methodology: A qualitative, descriptive and interpretative study was conducted. A total of 17 semi-structured interviews were performed. Van Manen's holistic approach was used in the analysis.

Results: The emergent themes were feelings experienced regarding curricular innovation; the difficult implementation of competencies; the profound changes; and a good teaching.

Conclusion: The study allowed us to understand the meaning of curricular innovation from the students' perspective and provided relevant information for curricular redesign. It allowed us to reflect on the teaching/learning process of competency-based curricula in Latin-America.

Keywords: education, nursing; curriculum; students, nursing; competency-based education

\section{Resumen}

Marco contextual: La educación en enfermería en esta última década ha iniciado importantes cambios curriculares basados en la formación en competencias, por lo que implica un reto para la disciplina, el definir qué competencias son relevantes a desarrollar en los estudiantes.

Objetivo: Comprender las experiencias vividas por los (as) estudiantes de la Universidad Católica del Maule acerca de la formación basada en competencias.

Metodología: Se enmarca bajo el paradigma cualitativo, descriptivo e interpretativo, se realizaron 17 entrevistas semiestructuradas. En el análisis se utilizó el enfoque holístico de Van Manen.

Resultados: Emergen temas como sentimientos experimentados con la innovación curricular, la implementación de competencias es difícil, el cambio es profundo, y una buena docencia, valoran el acompañamiento y la experiencia clínica del docente.

Conclusión: El estudio permitió conocer el significado que tiene la innovación curricular desde la perspectiva de los estudiantes, aporta información relevante para el rediseño curricular y permite reflexionar acerca del proceso formativo de los currículos por competencias en el espacio latinoamericano.

Palabras clave: educación en enfermería; curriculum; estudiantes de enfermería; educación basada en competencias

*Ph.D., RN, Catholic University of the Maule, 3460000, Chile [mpoblete@ucm.cl].Contribution to the article: principal investigator; research design; data collection and processing of qualitative data; analvsis of the results; studv conclusions; article writing and revision. Address for correspondence: 10 Norte 1628,3460000 , Talca, Chile.

**MSc., RN, Catholic University of the Maule, 3460000, Chile [ccofre@ucm.cl]. Contribution to the article: data collection and processing of qualitative data; analysis of the results and conclusions. ***Ph.D., RN, Catholic University of the Maule, 3460000, Chile [vguerra@ucm.d]. Contribution to the article: analysis of the results and study conclusions; article writing and revision. ****MSc., RN, Catholic University of the Maule, 3460000, Chile [cmino@ucm.cl]. Contribution to the article: analysis of the results and conclusions; literature search; article writing and revision. *****Ph.D. RN, Catholic University of the Maule, 3460000, Chile [pceballos@ucm.cl]. Contr bution to the article: analysis of the results and conclusions; literature search; article writing and

revision. the article: data collection; article revision.

\section{Resumo}

Enquadramento: A educação em enfermagem, nesta última década, tem iniciado importantes mudanças curriculares com base na formação de competências, promovendo um desafio para a disciplina de definir quais as competências relevantes para que os estudantes desenvolvam.

Objetivo: Compreender as experiências dos(as) estudantes da Universidade Católica de Maule sobre formação baseada em competências.

Metodologia: Estudo descritivo e interpretativo de natureza qualitativa, por meio de 17 entrevistas semiestruturadas. Para a análise, utilizou-se a abordagem holística de Van Manen.

Resultados: Os temas emergentes foram: sentimentos vivenciados com a inovaçáo curricular, dificuldades na implementação de competências, o facto de a mudança ser profunda e uma boa docência valorizam o acompanhamento e a experiência clínica do professor.

Conclusáo: $\mathrm{O}$ estudo permitiu conhecer o significado que tem a inovaçáo curricular na perspectiva dos estudantes, forneceu informaçóes relevantes para o redesenho curricular e permitiu refletir sobre o processo formativo dos currículos baseados em competências no espaço latino-americano.

Palavras-chave: educação em enfermagem; currículo; estudantes de enfermagem; educação baseada em competências 


\section{Introduction}

In the past decades, the competency-based curriculum emerged from the Tuning Project in the European Union. Since then, Chilean universities have begun to adapt the university system to this new reality, culminating in their adherence to this educational paradigm (Consejo de Rectores de las Universidades Chilenas, 2011). This paradigm shift resulted from the need to bring the university closer to the job market and effectively facilitate the integration of professionals into the job market.

According to Villarroel and Bruna (2014), the competency-based curriculum model has both advantages and challenges. Its main benefits include the contextual and disciplinary nature of this curriculum model, as well as the focus on the achievement of performance. In addition, it can be measureable and inclusive. One of the challenges is the training of university teachers about the competency-based model, which involves updating teachers' knowledge about teaching and evaluation methodologies. The competency-based curriculum requires not only the acquisition of knowledge, but also an emphasis on evaluation and learning as part of a continuum, in which learnings should be evaluated and evaluations should produce learning (Mateo \& Vlachopoulos, 2013).

For academics, it implies not only changing teaching practices, leaving their central role and placing the student at the center of learning, but also integrating knowledge from different disciplines, which requires a coordinated teamwork.

With regard to this paradigm shift in higher education, it should be noted that dissident perspectives emerge in the academy. Some authors see this paradigm as an imposition of the neoliberal market and a process of global market expansion that will lead to the commodification of education, which perpetuates cultural hegemony. Therefore, curricular changes must be thoroughly analyzed (Angulo \& Redon, 2011; Moreno, 2010).

This article shows the results of the study aimed to understand students' experiences regarding competency-based training, in its first years of implementation, as part of the internal project of the Catholic University of the Maule "Escuela de Enfermería en Innovación Curricular: Percepción de Estudiantes y Docentes" (School of Nursing undergoing Curriculum Innovation: Faculty and Students' Perception).

\section{Background}

A competency-based curriculum requires the active participation of both teachers and students in this change, so that it does not become a mere institutional discourse.

The School of Nursing at the Catholic University of the Maule (Universidad Católica del Maule - UCM) committed to the challenge of implementing a competency-based curriculum. This curriculum is designed to allow students to fully develop their skills, enabling their optimal performance to meet the demands of the current job market.

The curricular innovation took place within the scope of the MECESUP UBB0607 project entitled Innovación Académica en Escuelas de Enfermería en red para enfrentarse a desafios de la educación terciaria (Academic Innovation in Nursing Schools in Networks to Address the Challenges in Tertiary Education). This work started in 2007 as part of a network between the Valparaiso University, the University of Bío Bío, the Austral University of Chile, and the UCM (Universidad Católica del Maule, 2012).

Based on this work, the School of Nursing at the UCM changed its study plan in March 2013 and added integrative learning modules to students' training. The current training model is the outcome of a disciplinary challenge in decision-making on the most relevant competences, skills, and abilities for students to develop during their educational path.

For this reason, four years after the implementation of the curriculum, the researchers decided to assess students and teachers' experiences of the changes in the model by conducting the internal project Escuela de Enfermería en Innovación Curricular: Percepción de Estudiantes y Docentes (Nursing School in Curriculum Innovation: Perception of Students and Teachers) in the UCM. 


\section{Research questions}

What was students experience of the nursing teaching/learning process implemented at the UCM?

What was students experience with the teaching/learning process provided by teachers?

\section{Methodology}

The study was developed using the qualitative paradigm, as it describes and interprets students' accounts.

Participants were selected using the convenience sampling method based on data saturation criteria (Creswell, 2013). The following inclusion criteria were applied: male and female nursing students who were in a regular situation (with innovative curriculum); who were attending the third to eighth semester; and who voluntarily agreed to participate in the study. The sample characteristics are described below.

Students attended different years of nursing degree: four students were in the second year, six were in the third year, and seven were in the fourth year. The participants' age ranged between 20 and 30 years. The sample was composed of seven male students and 10 female students.

To ensure the compliance with all ethical principles, Exequiel Emanuel's seven ethical requirements for research were respected; the project was assessed by the Scientific Ethics Committee of the UCM, and each participant was asked to sign an informed consent form.

Data were collected through semi-structured interviews to the 17 sampled participants. The interviews were carried out in the School of Nursing in a safe environment, depending on the participants' availability. Each interview lasted 20 to 30 minutes. The researchers recorded the interviews and transcribed them in full, using the holistic approach or sentence approach, the selective approach, and the detailed approach according to Van Manen (1997).

\section{Results}

Four main themes emerged from data analysis. These themes revealed students' expe- riences of the teaching/learning process implemented at the UMC and the teaching/ learning process provided by their teachers. These topics derived from the accounts of several participants, in the following order: Theme 1: Feelings experienced; Theme 2: The difficult implementation of competencies; Theme 3: The profound changes; and Theme 4: Good teaching.

\section{Theme 1: Feelings experienced}

Students reported several feelings concerning the changes in the learning model, as shown by the following accounts:

"This is a new curriculum. It makes me feel like a guinea pig in some aspects." (Participant no. 1, eighth semester; July, 2016).

"Since I found out that the study plan had changed, we entered the university and were afraid to test the curriculum model, we were going to do so-called experiments, so I was afraid." (Participant no. 2, eighth semester; July, 2016).

They already know of our experience, like we were the trial, we feel at a disadvantage because, for example, there are things that were tested on us and then were implemented in a different way in the year after, that is, with the second generation (Participant no. 4 , eighth semester; August, 2016).

Some of the students who experienced the changes in the model reported feelings such as fear, confusion, and the sense of being at a disadvantage and of being an "experiment", all of which are described in the following accounts:

"It also creates a bit of confusion, the moment we are living in classes because, for example, the day before yesterday, we observed an adult admission and, after half an hour, a pediatric admission" (Participant no. 4, the eighth semester; August, 2016).

"We also feel the uncertainty. It's how I feel, the uncertainty that all the courses are one and the same" (Participant no. 1, eighth semester; July, 2016).

On the other hand, the implementation of the new curriculum sometimes involves integrating different sets of knowledge so that knowledge can emerge as a whole. The students in this study reported that the integra- 
tion of some modules caused them confusion and uncertainty, as described in the next theme.

\section{Theme 2: The difficult implementation of competencies}

The students who began their training with the new curriculum did not observe the changes in the teachers, as described in the following accounts:

"I think that the teacher did not adapt very well, he kept on giving the same contents, in the same way as the year before." (Participant no. 2, eighth semester; July, 2016). "During the first generation classes, [the teacher] kept on using the old study plan" (Participant no. 1, eighth semester; July, 2016).

Students reported that teachers taught classes using the same methodologies as the objective-based study plan from previous years.

Their accounts also reflect how contents were not contextualized in some modules:

We can say that, sometimes, they turn a bit more to the medical area rather than nursing because medical teachers' approach is different; other times, they focused on extremely medical topics and we say that this is not useful. (Participant no. 3, eighth semester; August, 2016)

In competency-based curricula, the different sets of knowledge should be contextualized within the discipline, so that competences are fully acquired. Students perceive that this knowledge must be oriented towards nursing.

\section{Theme 3: The profound changes}

Students in the first years of the degree reported difficulties in adapting to a competency-based curriculum. They experience it as a major change, with a heavy and extremely demanding academic workload, as can be seen in the following accounts:

"Micro was difficult for me. There's no exam but the subject in itself, because it is a more autonomous learning, it was difficult for me. I've been studying a lot and still haven't assimilated it" (Participant no. 2, fourth semester; August, 2016).
"I feel that the change is big, there's too much to study, too much to keep up with because there's a lot for me to do." (Participant no. 1, fourth semester; August, 2016)

This year no, no. It's terrible. We have five specialties, and we have classes every day, 4 hours of classes every day, then we finish at 7 in the afternoon, although we actually never finish at 7 , the study plan is very intense. (Participant no. 3, fourth semester; August, 2016)

Students entered the university with a traditional objective-based model and moved to a competency-based model. For this reason, they perceive the change to be extremely significant. They emphasized the high academic workload and autonomous work.

\section{Theme 4: Good teaching}

Students' accounts underlined teachers' importance given their clinical experience and supervision of students' learning.

"Supervision is much more effective at school, we're closer to the teachers, they always have a solution." (Participant no. 1, eighth semester July, 2016).

This proximity with the teacher in the specialties makes the content much clearer.

It was the teacher. I feel that she encouraged me not give up and move on. I feel that she supported me a lot, so I feel that this was a very good experience that motivates us to continue. We may fall but we find the courage to go on and finish the degree. (Participant no. 2, sixth semester; August, 2016).

The relevance of teachers' experience for students in the final years of the degree can be seen in the following account:

"I think that experience is one of the most valuable things that a person can have and our teachers gave us this experience so that we can become good professionals, so that we don't make mistakes." (Participant no. 5, eighth semester; July, 2016).

Nursing students value their teachers' clinical experience and supervision, which give them confidence to acquire knowledge. 


\section{Discussion}

Students' accounts about the curricular innovation showed that, during their first academic years, students suffer from stress and have difficulty in adapting to the change from a traditional education (secondary education) to a competency-based education (higher education). These difficulties, for example, emerge from the greater amount of autonomous work. Therefore, these findings are similar to those found by some authors who observed that, although students valued the new methodologies used in higher education, they prefer a more traditional education system in the first years because of their experience in secondary education (Vollrath, Angelo, \& Muñoz, 2011; Macilla \& Ricouz, 2016).

Students' accounts also showed that teachers continued using the same teaching methodologies from the previous curriculum, rather than the new ones from the competency-based curriculum. Students also experienced some difficulties in terms of the contextualization of contents, which is similar to results found in other Latin-American nursing schools (Paranhos \& Mendes, 2010; Moreno Tello, Prado Moncivais, \& García Avendaño, 2013; Pecina Leyva, 2015).

The implementation of the competency-based curriculum will probably take more time and require more training for teachers to change methodologies and adapt to this new model. According to several studies, teachers perceive themselves as not being able to handle everything involved in this innovative process, making them feel uncertain about their responsibility for efficiently performing their work (Rivas, Bustos, Rivas, Lagos, \& San Martín, 2012; Asún Inostroza, Zuñiga Ribas, \& Ayala Reyes, 2013; Villa, Campo, Arranz, Villa, \& García, 2013).

Conversely, students' accounts showed that they value good teachers who supervise them and pass on their clinical experience. This result was also found by Betancourt, Muñoz, Meighi, and Santos (2011), to whom teachers' transmission of both knowledge and skills acquired in their own professional experience is a key aspect of nursing professional training. With regard to the value of the teachers' supervision, several Latin-American studies have shown that it is essential for students, particularly for the integration of theory into practice. This is particularly relevant for students during their final years of training, where they value more their teachers' ability to guide them and strengthen their confidence, as well as to facilitate learning and the transition from student to professional (Betancourt et al., 2011; Peixoto \& Peixoto, 2016).

\section{Conclusion}

The implementation of the competency-based curriculum has been a challenge for the School of Nursing at the UCM. The move from a traditional curriculum toward a competency-based curriculum should be gradual and involve the participation and commitment of not only higher education institutions, which should provide the necessary resources, but also teachers, who should implement a competency-based pedagogy.

In turn, it is possible to conclude that students entering higher education need to develop skills to perform autonomous work in the early years. To achieve this, they need support and resources that promote these skills. Therefore, based on the results of this study, the change should be gradual and highly supervised with a view to reducing stress and school dropout.

Teachers' supervision and experience, both in the discipline and in clinical practice, are key factors in this process. Therefore, we urge nursing teachers to develop these aspects to encourage learning and train professionals who are more caring and empathetic toward patients. Finally, the implementation of a competency-based curriculum is a constant and difficult challenge to nursing schools. This study aimed to provide the necessary information to redesign the curriculum, taking into account that the improvement of nursing curricula requires continuous and permanent work.

\section{References}

Angulo, F., \& Redon, S. (2011). Competencias y contenidos: Cada uno en su sitio en la formación docente. Estudios Pedagógicos, 37(2), 281-299. doi: 
10.4067/S0718-07052011000200017

Asún Inostroza, R., Zuñiga Ribas, C., \& Ayala Reyes, M. C. (2013). La formación por competencias y los estudiantes: Confluencias y divergencias en la construcción del docente ideal. Revista Calidad en la Educación, 38, 277-304. doi: 10.4067/S071845652013000100008

Betancourt, L., Muñoz, L. A., Merighi, M. A., \& Santos, M. F. (2011). El docente de enfermería en los campos de práctica clínica: Un enfoque fenomenológico. Revista Latinoamericana de Enfermagem, 19(5), 1-9. doi: 10.1590/S0104-11692011000500018

Consejo de Rectores de las Universidades Chilenas. (2011). Innovación curricular en las universidades del consejo de rectores 2000 - 2010. Retrieved from http://sct-chile.consejoderectores.cl/documentos_ WEB/Innovacion_Curricular/2.Informe_INNOVACION_CURRICULAR.pdf

Creswell, J. (2013). Qualitative inquiry and research design: Choosing among five approaches. Los Angeles, CA: SAGE Publications.

Emanuel, E. (2003). ¿Qué hace que la investigación clínica sea ética? siete requisitos éticos. En Lolas, F y Quezada, A. Pautas éticas de investigación en seres humanos: nuevas perspectivas. Programa regional de Bioética OPS/OMS. Santiago de Chile.

http://www.libros.uchile.cl/files/presses/1/monographs/258/submission/proof/files/assets/basic-ht$\mathrm{ml} /$ index.html\#page 84

Macilla, J., \& Ricouz, A. (2016). Vivencia del rol docente clínico de enfermeras de hospitales del sur de Chile. Revista Ciencia y Enfermería, 22(1), 101111. doi: 10.4067/S0717-95532016000100009

Mateo, J., \& Vlachopoulos, D. (2013). Reflexiones en torno al aprendizaje y a la evaluación en la universidad en el contexto de un nuevo paradigma para la educación superior. Educación XX1, 16(2), 183 208. doi:10.5944/educxx1.2.16.10338

Moreno Tello, M. A., Prado Moncivais, E. N., \& García Avendaño, D. J. (2013). Percepción de los estudiantes de enfermería sobre el ambiente de aprendizaje durante sus prácticas clínicas. Revista Cuidarte, 4(1), 444-449. doi: 10.15649/cuidarte.v4i1.3

Moreno, T. (2010). El currículo por competencias en la universidad: Más ruido que nueces. Revista de la Educación Superior, 39(2), 77-90.

Paranhos, V. D., \& Mendes, M. M. (2010). Currículo por competencia y metodología activa: Percepción de estudiantes de enfermería. Revista Latino-Americana de Enfermagem, 18(1), 109-115. doi: 10.1590/ S0104-11692010000100017

Pecina Leyva, R. M. (2015). Percepción del estudiante de enfermería sobre la calidad del proceso enseñanza aprendizaje. Revista Iberoamericana de Producción Académica y Gestión Educativa, 2. Retrieved from https://www.pag.org.mx/index.php/PAG/article/ viewFile/287/332

Peixoto, N. M., \& Peixoto, T. A. (2016). La práctica reflexiva en estudiantes de enfermería en la enseñanza clinica. Revista de Enfermagem Referência, 4(11), 121-132. doi: 10.12707/RIV16030

Rivas, E., Bustos, L., Rivas, A., Lagos, X., \& San Martín, S. (2012). Experiencia subjetiva de estudiantes y docentes que vivencian un cambio curricular. Ciencia y Enfermería, 18(3), 101-110. doi: 10.4067/S0717-95532012000300010

Universidad Católica del Maule. (2012). Proyecto formativo profesional de pregrado de la carrera de enfermería, Sede Talca y Curicó: Decreto de Rectoría 87/ 2012 del 9 de noviembre. Retrieved http://www. secretaria-general.ucm.cl/docs/Decreto\%20R.872012.pdf

Van Manen, M. (1997). Researching lived experience: Human science for an action sensitive pedagogy. London, England: The Althouse Press.

Villa, A., Campo, L., Arranz, S., Villa, O., \& García, A. (2013). Valoración del profesorado de magisterio sobre el aprendizaje basado en competencias implantado. Revista de Curriculum y Formación del Profesorado, 17(3), 35-55. Retrieved from https://recyt.fecyt.es/index.php/profesorado/article/ view/41981/23964

Villarroel, V., \& Bruna, D. (2014). Reflexiones en torno a las competencias genéricas en educación superior: Un desafío pendiente. Psicoperspectivas: Individuo y Sociedad, 13(1), 23-24. doi: 10.5027/ PSICOPERSPECTIVAS-VOL13SSUE1-FULLTEXT-335

Vollrath, A., Angelo, M., \& Muñoz, L. (2011). Vivencia de estudiantes de enfermería de la transición a la práctica a la práctica profesional: Un enfoque fenomenológico social. Texto \& Contexto - Enfermagem, 20(Esp.), 66-73. doi: 10.1590/S010407072011000500008 